\title{
Role of intertidal wetlands for tidal and storm tide attenuation along a confined estuary: a model study
}

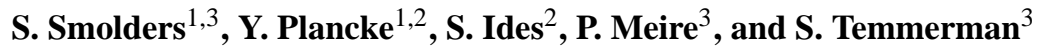 \\ ${ }^{1}$ Flanders Hydraulics Research, Antwerp, Belgium \\ ${ }^{2}$ Antwerp Port Authority, Antwerp, Belgium \\ ${ }^{3}$ University of Antwerp, Ecosystem Management research group, Antwerp, Belgium \\ Correspondence to: S. Smolders (svensmolders@gmail.com)
}

Received: 1 March 2015 - Published in Nat. Hazards Earth Syst. Sci. Discuss.: 8 May 2015

Revised: 21 July 2015 - Accepted: 23 July 2015 - Published: 30 July 2015

\begin{abstract}
Coastal lowlands and estuaries are subjected to increasing flood risks during storm surges due to global and regional changes. Tidal wetlands are increasingly valued as effective natural buffers for storm surges by dissipating wave energy and providing flood water storage. While previous studies focused on flood wave attenuation within and behind wetlands, this study focuses on the effects of estuarine wetland properties on the attenuation of a storm tide that propagates along the length of an estuary. Wetland properties including elevation, surface area, and location within the estuary were investigated using a numerical model of the Scheldt estuary (Belgium, SW Netherlands). For a spring tide lower wetland elevations result in more attenuation of high water levels along the estuary, while for a higher storm tide higher elevations provide more attenuation compared to lower wetland elevations. For spring and storm tide a larger wetland surface area results in a better attenuation along the estuary up to a threshold wetland size for which larger wetlands do not further contribute to more attenuation. Finally a wetland of the same size and elevation, but located more upstream in the estuary, can store a larger proportion of the local flood volume and therefore has a larger attenuating effect on upstream high water levels. With this paper we aim to contribute towards a better understanding and wider implementation of ecosystem-based adaptation to increasing estuarine flood risks associated with storms.
\end{abstract}

\section{Introduction}

Deltas and estuaries worldwide are subjected to an increasing risk of flooding disasters. Recent examples of storm surge flood disasters include Hurricane Katrina in New Orleans (2005), Hurricane Sandy in New York (2012) and Typhoon Haiyan in the central Philippines (2013). Global climate warming accelerates sea level rise (Church et al., 2013) and there is growing consensus that it increases the intensity of storms and associated storm surges (Emanuel, 2005; Webster et al., 2005; Knutson et al., 2010; Lin et al., 2012; Grinsted et al., 2013). These global change effects combined with regional changes, including growing coastal populations and land subsidence, expose low-lying deltas and estuaries to increasing storm surge flood risks (Hanson et al., 2011; Hallegatte et al., 2013). It is estimated that in 2005 around 40 million people and USD 3000 billion of assets were located in flood-prone coastal cities, and that these numbers could increase to 150 million people and USD 35000 billion of assets by 2070 (Hanson et al., 2011).

For low-lying coasts, deltas and estuaries, the presence of wetland ecosystems, such as tidal marshes and mangroves, is considered to play an important role in the landward attenuation of storm surge flood waves (Temmerman et al., 2013). An increasing number of studies shows that these wetland ecosystems can reduce the height of storm surges due to their dense vegetation and the friction they exert on landward propagating flood waves (Costanza et al., 2008; Das and Vincent, 2009; Krauss et al., 2009; Wamsley et al., 2010; Gedan et al., 2011; Temmerman et al., 2012; Zhang et al., 2012; Sheng et al., 2012; Liu et al., 2013; Barbier et al., 2013; Hu 


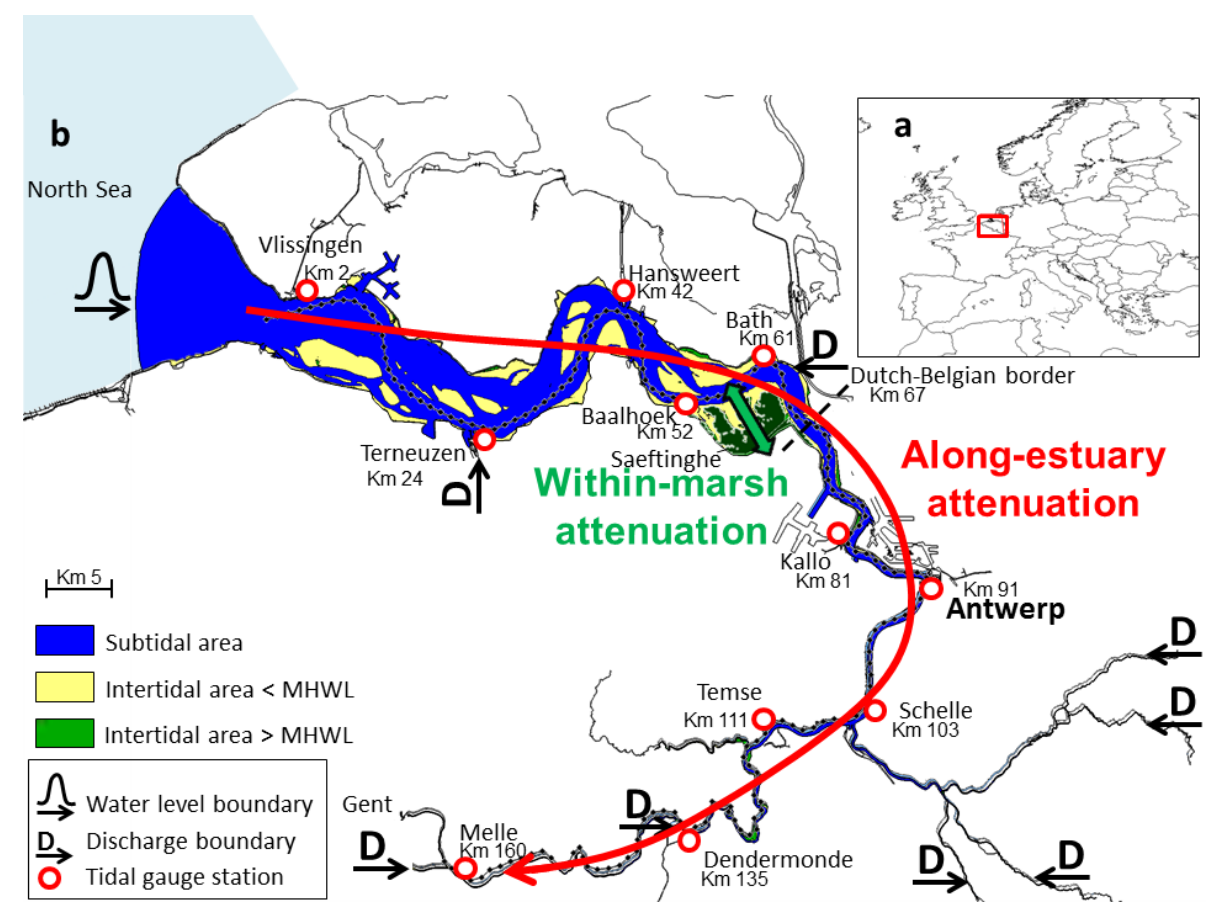

Figure 1. (a) Location of study area within Western Europe; (b) detail of location of the model domain, boundaries and main tidal gauge stations. Difference between within-wetland attenuation and along-estuary attenuation. Km indication along main estuarine channel.

et al., 2015). Unfortunately these wetland ecosystems are and have been under a lot of pressure due to urban, agricultural and industrial expansion. An estimated $25 \%$ of the world's intertidal estuarine habitat has been lost due to land reclamation (French, 1997). Over the last 3 decades globally, $50 \%$ of salt marsh and $35 \%$ of mangrove ecosystems have been lost or have degraded due to human activity (Alongi, 2002; Millenium Ecosystem Assessment, 2005). With the loss of these wetland ecosystems, their protective function is also lost, making low-lying coasts, deltas and estuaries more vulnerable to flood risks. Although traditional hard engineering solutions, like dikes and storm surge barriers, are widely perceived as the ultimate solution to combat flood risks, the combination with ecosystem-based flood defense - i.e. the conservation and restoration of tidal wetlands for flood attenuation - is likely to be more sustainable and cost-effective in the long term for many critical deltas and estuaries worldwide (Temmerman et al., 2013). Wetland ecosystems can effectively keep up with sea level rise by natural sediment accretion (Kirwan and Temmerman, 2009; Kirwan et al., 2010), which makes them in the long term more sustainable than static engineering structures. Apart from storm surge attenuation, wetlands also effectively attenuate wind waves and associated shoreline erosion, even during extreme wave conditions (Möller et al., 2014). They further deliver additional ecosystem services like carbon sequestration, water quality regulation, nutrient cycling, biological production, and many others (Barbier et al., 2011). Only a limited number of places around the world are implementing that ecosystembased flood defense on a large scale, such as the conversion of reclaimed land back into wetlands in the UK (Pethick, 2002; French, 2006) and Belgium (Cox et al., 2006; Maris et al., 2007; Vandenbruwaene et al., 2011), and more in-depth research is needed in order to stimulate and support more widespread implementation (Temmerman et al., 2013). Harmonizing hard engineering solutions, where necessary, with ecosystem-based solutions, where possible, is a challenge for future development and sustainability of estuaries and coasts.

Existing studies on the degree of storm surge height reduction by tidal wetlands rely on fragmentary observations of peak water levels within and behind tidal wetlands (e.g. Lovelace, 1994; McGee et al., 2006; Krauss et al., 2009; Wamsley et al., 2010) and on hydrodynamic model simulations (e.g. Resio and Westerink, 2008; Loder et al., 2009; Wamsley et al., 2009, 2010; Zhang et al., 2012; Temmerman et al., 2012; Sheng et al., 2012; Liu et al., 2013; Hu et al., 2015). These studies reported that peak water levels can be reduced by 5 to $50 \mathrm{~cm} \mathrm{~km}^{-1}$ when storm surges travel through tidal marshes or mangroves, causing flood wave energy loss due to increased bottom friction. This type of flood attenuation is further referred to in this paper as withinwetland attenuation (see Fig. 1). Model studies have demonstrated that the degree of within-wetland attenuation is dependent on wetland properties, such as the size, elevation and vegetation type (e.g. Loder et al., 2009; Wamsley et al., 2009, 2010; Zhang et al., 2012; Temmerman et al., 2012; Sheng et 
al., 2012; Hu et al., 2015), as well as properties of the storm, such as the strength, duration, forward speed and track of the storm (e.g. Resio and Westerink, 2008; Loder et al., 2009; Wamsley et al., 2010; Sheng et al., 2012; Liu et al., 2013; Hu et al., 2015). With respect to the effect of wetland properties, rates of within-wetland attenuation were found to decrease with lower bottom friction (= less vegetation biomass) and with a higher bed elevation (e.g. Loder et al., 2009; Wamsley et al., 2009, 2010; Temmerman et al., 2012).

Whereas the existing studies discussed above focus on within-wetland attenuation of storm surges, to our knowledge very few studies are dedicated to what we call here along-estuary attenuation, i.e. the contribution of estuarine intertidal wetlands to attenuation of storm tides that propagate upstream along an estuary (see Fig. 1). For example Bullock and Acreman (2003) reviewed studies on freshwater wetlands and flooding along non-tidal rivers, highlighting that floodplain wetlands reduce or delay floods. The attenuation capacity of coastal or estuarine wetlands is, however, not discussed. Townend and Pethick (2002) examined the effects of managed retreat in the UK - i.e. the conversion of reclaimed land into intertidal wetlands - on estuarine flooding. They focused on sea level rise and the effect of size of intertidal area on ebb or flood dominance. They found that an increase in intertidal storage (caused by managed retreat) increases the ebb dominance of an estuary. French (2008) performed a hydrodynamic study of the effects of estuarine intertidal wetland creation by managed retreat, focusing on the effects of increased intertidal area on increased tidal currents and discharges in the estuary. However, studies that focus on how much intertidal wetlands contribute to along-estuary attenuation of storm tides, and to which extent the degree of attenuation is affected by wetland properties such as size, elevation, and location along the estuary, are as far as we know lacking in the international scientific literature.

In this paper we present a 2-D hydrodynamic model that has been calibrated and validated for tides and storm tides in the Scheldt estuary (Belgium and SW Netherlands), and use the model to investigate the effect of scenarios with different intertidal wetland properties, including wetland elevation, size and location along the estuary, on along-estuary attenuation of tides and storm tides.

\section{Material and methods}

\subsection{Study area}

The Scheldt estuary is situated in the Netherlands and Belgium (Fig. 1a). The connection with the North Sea is formed by the Vlakte van de Raan, a shallow water area with several deeper channels. The part of the estuary from the mouth until the Dutch/Belgian border (located at $67 \mathrm{~km}$ from the mouth, measured along the thalweg) is called Western Scheldt and is characterized by different ebb and flood channels surround- ing large intertidal sand and mud flats. The part further upstream from the border until Ghent (located at $170 \mathrm{~km}$ from the mouth) (Fig. 1b) is called Sea Scheldt and is characterized by a single channel bordered by much smaller intertidal flats and marshes.

The estuary mouth near Vlissingen (km 2) (Fig. 1b) is approximately $5 \mathrm{~km}$ wide and flood enters twice a day with an average flood volume of $1.04 \mathrm{Gm}^{3}$ (Baeyens et al., 1998). The funnel shape of the estuary amplifies the tidal range, for mean spring and neap tides respectively, from 4.46 and $2.97 \mathrm{~m}$ at the mouth to 5.93 and $4.49 \mathrm{~m}$ near Schelle (km 103) (Fig. 1b). Further upstream friction dampens the tidal wave, which has still a mean tidal range of 2.24 and $1.84 \mathrm{~m}$ for spring and neap tides respectively near Ghent ( $\mathrm{km} \mathrm{170),}$ where the tide is stopped by a weir-lock construction. The total discharge of the Scheldt and tributaries (on average 120 $\mathrm{m}^{3} \mathrm{~s}^{-1}$ ) is very small compared to the tidal volume (Meire et al., 2005; Van Damme et al., 2005).

The Scheldt estuary occupies an area of 35000 ha of which 9000 ha $(26 \%)$ is intertidal area (yellow area in Fig. 1b) and 2800 ha $(8 \%)$ are vegetated marshes located above mean high water level (MHWL) (dark green areas in Fig. 1b) (Vandenbruwaene et al., 2013). Saeftinghe $\left(51.33^{\circ} \mathrm{N}, 4.17^{\circ} \mathrm{E}\right)$ is the largest intertidal area (3500 ha) encompassing sand and mudflats, and tidal marsh within the brackish zone of the estuary, with a local mean tidal range of $4.88 \mathrm{~m}$ and a salinity of 5-18 PSU. From 1931 to 2009 a long-term mean high water level (MHWL) rise was observed in Saeftinghe with a rate of $5.7 \mathrm{~mm} \mathrm{yr}^{-1}$ (Wang and Temmerman, 2013).

In the Scheldt estuary large-scale historic wetland reclamation - about 100000 ha of intertidal area has been reclaimed over the last 1000 years of which about 15000 ha since 1800 - has largely contributed to increasing water levels in the remaining estuarine channels. Nowadays tidal marsh restoration on formerly reclaimed land is brought into large-scale practice as an essential part of the flood defense system (Meire et al., 2014). Saeftinghe is the largest remaining intertidal area today with 3000 ha.

\subsection{TELEMAC 2-D model}

A 2-D hydrodynamic model of the Scheldt estuary and tidal tributaries was made with the finite element model software TELEMAC 2-D (v6p0). The hydrodynamics are solved by the depth-averaged Saint-Venant equations. The triangular irregular mesh consists of 42632 nodes and 75889 elements. Its resolution ranges from $300 \mathrm{~m}$ in the mouth area to $150 \mathrm{~m}$ in the Western Scheldt and $50 \mathrm{~m}$ near Antwerp ( $\mathrm{km} \mathrm{91)} \mathrm{to}$ $5 \mathrm{~m}$ at the upstream end of the model. The bathymetry of 2009 ( 20 by $20 \mathrm{~m}$ resolution from mouth to the border and 1 by $1 \mathrm{~m}$ further upstream, obtained from single- and multibeam sonar measurements) was interpolated onto the mesh with the bathymetric depth being negative below and positive above the reference plane, i.e. NAP, the Dutch reference level which is about local mean sea level. A time series of 
measured water levels with 10 min time interval was used as boundary condition on the seaward boundary (Fig. 1b). Upstream there are eight boundaries with an imposed daily averaged discharge (Fig. 1b). The timestep was set to $6 \mathrm{~s}$. A constant viscosity model was used with a value of $10^{-4} \mathrm{~m}^{2} \mathrm{~s}^{-1}$.

Since bottom friction is regarded as the main sink for momentum this parameter was used for calibration of the model. Telemac uses the Chézy roughness formulation, with the Chézy roughness coefficient, $C$, defined as $C=D^{1 / 6} \cdot n^{-1}$, where $D=$ water depth $[\mathrm{m}]$ and $n=$ the predefined Manning roughness coefficient $\left[\mathrm{m}^{-1 / 3} \mathrm{~s}\right]$. The calibration period was March 2009. The model was calibrated on water levels for 22 tide gauge stations in the whole estuary (selected tide gauge stations are shown in Fig. $1 \mathrm{~b}$ as a red circle). The time series resolution of modelled and measured water levels is $10 \mathrm{~min}$. The bottom friction parameter (Manning coefficient) in the model between two successive tide gauge stations was altered in order to minimize the difference between measured and modelled water levels and phase for each tide gauge station. After calibration the model's performance was validated simulating the whole year 2009.

\subsection{Storms}

Storm surge generation by wind and atmospheric pressure effects were not explicitly taken into account in the model domain, assuming that wind and atmospheric pressure effects on water levels are mainly generated on the North Sea (e.g. Gaslikova et al., 2013), which was not included in the model domain. Measured storm surges are implicitly included in the imposed measured water levels at the seaward boundary of the model domain (Fig. 1b) (similarly as in Temmerman et al., 2012), and assuming that additional wind and atmospheric pressure effects on water levels within the estuarine model domain are limited because of the limited fetch length and limited water depths in such a narrow and shallow estuarine setting. Two real storm surges were included in the boundary conditions and were used for model validation. The first storm dated from 10 February 2009 and the second one from 6 December 2013. The storm return periods were calculated for the measured water levels at the mouth of the estuary according to Willems et al. (2007) and resulted in 2.4 and 20 years, respectively. Due to the extra wind upset high water levels at the seaward boundary of the model increased to 0.74 and $1.54 \mathrm{~m}$, for both storms respectively, above the astronomical calculated high water levels. For both storms time series of water level measurements were available for the entire estuary and so modelled water levels could be compared with measured ones, revealing an acceptable agreement between both (see model validation in Sect. 3.1). The 2013 storm was used in the scenario simulations.

\subsection{Scenarios}

In this paper we focus on the effect of the largest currently remaining intertidal area of Saeftinghe ( $3000 \mathrm{ha}$; Fig. 1b) on the storage of storm water and attenuation of the tidal wave travelling through the estuary. We differentiate between realistic $(R)$ and schematic $(S)$ scenarios. The realistic scenarios are always based on realistic, measured topography of the Saeftinghe area. The schematic scenarios use a simplified topography of a wetland, not drained by channels, but as a flat platform with a specific size and uniform elevation. Figure 2 provides a schematic summary of all scenarios. These scenarios are divided into three different groups depending on the main characteristic that is investigated: (1) wetland elevation, (2) wetland surface area, and (3) location (of the wetland along the length of the estuary). For all scenarios we compare water levels with a reference scenario (= the wetland geometry for year 2009 for realistic scenarios, and uniform platform elevation of $1.85 \mathrm{~m}$ NAP for the schematic scenarios, where $1.85 \mathrm{~m}$ NAP is the spatially averaged wetland elevation in 2009) for different locations along the length axis of the entire estuary. For all scenarios the bottom friction coefficient (Manning value) of the Saeftinghe area was set to a spatially constant value of $n=0.026 \mathrm{~m}^{-1 / 3} \mathrm{~s}$, which is representative for non-vegetated sediment surfaces (Chow, 1959; Phillips and Tadayon, 2006). The Saeftinghe area presently consists of a mixture of bare tidal flats and vegetated marshes, and furthermore for several historic scenarios that were studied (see next section below and Fig. 2) the largest part of the Saeftinghe intertidal area was not vegetated. Different bottom friction coefficients for the Saeftinghe area were tested beforehand to simulate possible presence of vegetation, and although these different values had an effect on the results, we chose to run all scenarios with the same spatially constant manning coefficient of $n=0.026 \mathrm{~m}^{-1 / 3} \mathrm{~s}$ for better comparison between the scenarios and to focus on the effects of the topographic-geometric properties of the wetland scenarios. The influence of the bottom friction on the within-wetland attenuation is not the focus of this paper.

\subsubsection{Wetland elevation}

For the realistic scenarios the measured bathymetries of 1931, 1963 and 2009 were used (see Wang and Temmerman, 2013). These scenarios are called P.R.1, P.R.2 and P.R.3 respectively, where $\mathrm{P}$ refers to platform elevation and $\mathrm{R}$ to realistic topography. The topography of 2009 was used in the calibrated and validated model and this scenario, P.R.3, will be used as a reference against which all other realistic scenarios will be compared. In 1931 this area was mostly only non-vegetated tidal flat with an average elevation of $0.85 \mathrm{~m}$ NAP (see small figure in Fig. 2). Through the years this area trapped a lot of sediments and a vegetated marsh started to develop (see Wang and Temmerman, 2013). In 1963 the average elevation was $1.40 \mathrm{~m} \mathrm{NAP}$ and in 2009 it was $1.85 \mathrm{~m}$ 


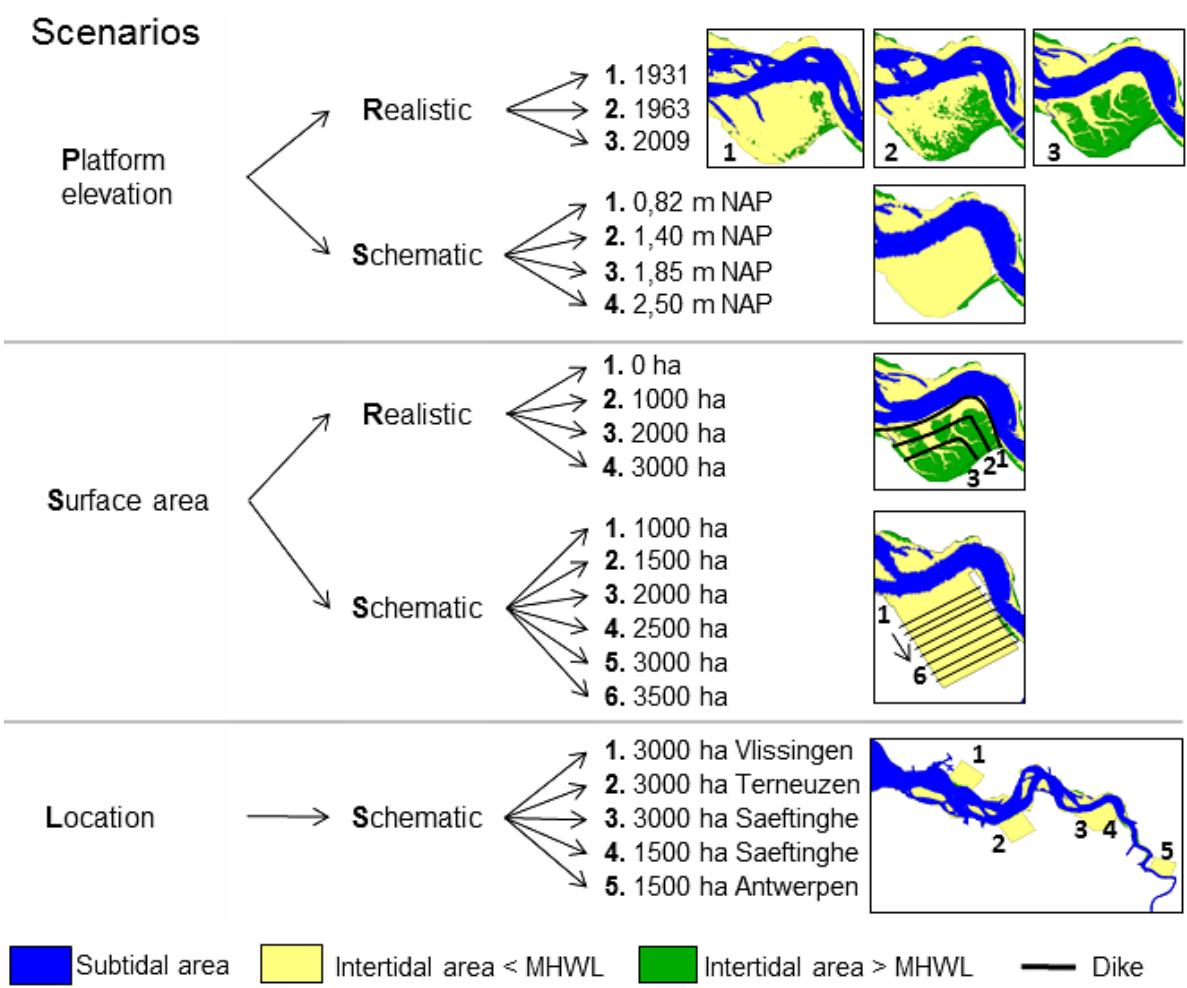

Figure 2. Schematic summary of the scenarios (see explanations in the text). The colours used in the small maps indicate the subtidal area $(<-2 \mathrm{~m}$ NAP) in blue, the intertidal area below MHWL ( $>-2 \mathrm{~m}$ NAP and $<2.5 \mathrm{~m} \mathrm{NAP}$ ) in light yellow and the intertidal area above MHWL ( $>2.5 \mathrm{~m}$ NAP) in green. The black line is an indication for the location of a dike.

NAP. In 2009 Saeftinghe developed into a vegetated marsh area with large non-vegetated drainage channels.

For the schematic scenarios a uniformly flat platform without drainage channels was implemented. The first three levels coincide with the average elevations of $1931(0.85 \mathrm{~m}$ NAP), 1963 (1.40 m NAP) and 2009 (1.85 m NAP) respectively. A fourth schematic scenario was added with an even higher platform elevation of $2.5 \mathrm{~m}$ NAP. These scenarios will be called P.S.1, P.S.2, P.S.3 and P.S.4, respectively, where P stands again for platform elevation and $\mathrm{S}$ for schematic topography (Fig. 2). Scenario P.S.3 with a platform elevation that is equal to the average wetland elevation in the realistic scenario P.R.3 will be used as a reference against which all schematic scenarios will be compared.

\subsubsection{Wetland surface area}

Here we test the impact of the size of a wetland on the tidal propagation within the estuary. For the realistic scenarios Saeftinghe was excluded from the estuary (S.R.1; where S stands for surface area), 2000 ha in the back of the wetland were excluded by creating a dike in the bathymetry leaving about 1000 ha intertidal area (S.R.2), 1000 ha was excluded in the back leaving about 2000 ha of intertidal area (S.R.3) and the scenario with full size area of about 3000 ha (S.R.4) is actually the same as the reference (P.R.3) (Fig. 2).
For the schematic scenarios a flat platform elevation of $2 \mathrm{~m}$ NAP was used. The Saeftinghe area was replaced by a larger rectangle at the same location. This area was made bigger for successive scenarios: 1000 ha (S.S.1), 1500 ha (S.S.2), 2000 ha (S.S.3), 2500 ha (S.S.4), 3000 ha (S.S.5) and 3500 ha (S.S.6) (Fig. 2).

\subsubsection{Wetland location along estuary}

We hypothesize that intertidal storage of a certain amount of water in the mouth area of an estuary will have different effects on tidal and storm surge attenuation than the same intertidal storage volume but located further upstream. To study this effect, different scenarios were simulated with a wetland area at different locations along the length of the estuary. These scenarios are all with schematic flat wetland. The first one is with a 3000 ha large square intertidal area near the mouth of the estuary, around $\mathrm{km} 10$ in the estuary (L.S.1; where L stands for location). Platform elevation was kept the same as in the schematic scenarios of surface area, i.e. $2 \mathrm{~m}$ NAP surface elevation. The second scenario is with the same area on the left bank around $\mathrm{km} 28$ in the estuary (L.S.2) (Fig. 2). Like the Saeftinghe area these new locations are also situated next to the main channel. For the third scenario a schematized flat version of the Saeftinghe area was used (L.S.3). Further upstream the total discharge through 


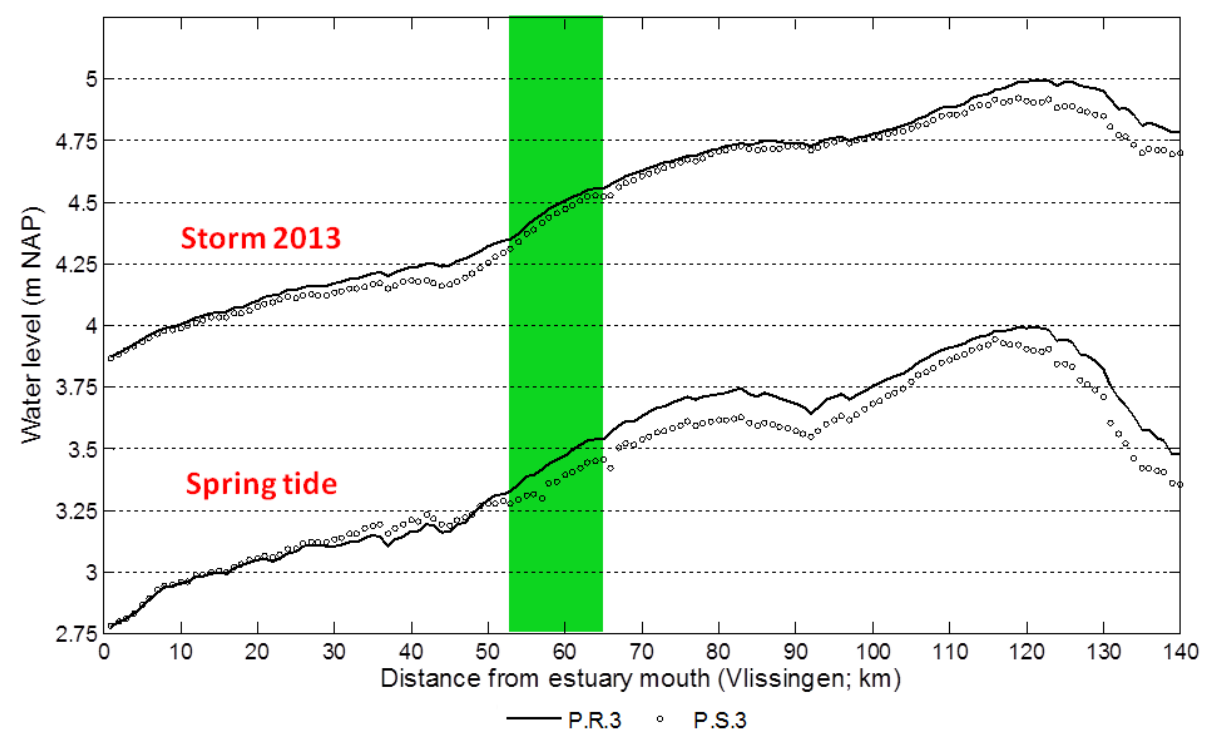

Figure 3. Peak water levels ( $y$ axis) as a function of distance along the estuary ( $x$ axis) during propagation of a spring tide and storm tide (2013) for the realistic (P.R.3) and schematic (P.S.3) reference scenario; the latter with equivalent platform elevation and surface area. The green band in the figure shows the location of the Saeftinghe wetland.

the main channel decreases and so the size of the flooding area was also decreased. For the fifth scenario a 1500 ha large area was placed near $\mathrm{km} 85$ on the right bank (L.S.5). To compare the results of this smaller sized area an extra scenario with a downscaled size of the Saeftinghe area (1500 ha) was made (L.S.4).

\section{Results}

\subsection{Model validation}

The hydrodynamic model was validated by simulating the whole year 2009. The model represents the measured tides reasonably well: for most tidal gauge stations along the estuary (Table 1), the average difference between all measured and modelled water levels is limited from 0.04 to $0.07 \mathrm{~m}$ (with a RMSE of 0.06 to $0.09 \mathrm{~m}$ ), except for the three most inland tidal gauge stations, where the average difference is 0.12 to $0.15 \mathrm{~m}$ and RMSE is 0.15 to $0.18 \mathrm{~m}$. Phase differences between the moments of high and low water stayed below $20 \mathrm{~min}$ for all stations. For storm tide attenuation the most important variable is the high water level along the estuary. Without special calibration for storm tides, the model performed fairly well in reproducing the two storm tides in the estuary, with average differences between measured and modelled high water levels between 0.01 and $0.22 \mathrm{~m}$ for the 2009 storm, and between 0.06 and $0.20 \mathrm{~m}$ for the 2013 storm (Table 1).
Table 1. Average and RMSE (for the whole year 2009) of difference in measured and modeled water level $(\Delta \mathrm{WL})$ for tide gauge stations with different distance from the estuary mouth. Difference between measured and modelled high water level ( $\triangle \mathrm{HWL}$ ) for the storm of 9 February 2009, and the storm of 6 December 2013.

\begin{tabular}{|c|c|c|c|c|}
\hline $\begin{array}{l}\text { Distance } \\
\text { from } \\
\text { estuary } \\
\text { mouth } \\
(\mathrm{km})\end{array}$ & $\begin{array}{c}\text { Avg } \\
\Delta \mathrm{WL} \\
2009 \\
(\mathrm{~m})\end{array}$ & $\begin{array}{c}\text { RMSE } \\
\text { avg } \\
\Delta \text { WL } \\
2009 \\
\text { (m) }\end{array}$ & $\begin{array}{c}\Delta H W L \\
\text { storm } \\
2009 \\
(\mathrm{~m})\end{array}$ & $\begin{array}{c}\Delta \mathrm{HWL} \\
\text { storm } \\
\text { Dec } 2013 \\
\text { (m) }\end{array}$ \\
\hline 2 & 0.04 & 0.06 & 0.01 & 0.06 \\
\hline 21 & 0.04 & 0.06 & 0.10 & 0.17 \\
\hline 36 & 0.06 & 0.08 & 0.04 & 0.16 \\
\hline 52 & 0.07 & 0.09 & 0.17 & 0.18 \\
\hline 78 & 0.06 & 0.08 & 0.21 & 0.18 \\
\hline 91 & 0.15 & 0.18 & 0.22 & 0.20 \\
\hline 98 & 0.14 & 0.17 & 0.16 & 0.09 \\
\hline 122 & 0.12 & 0.15 & 0.11 & 0.15 \\
\hline
\end{tabular}

High water levels rise starting from the estuary mouth until $\mathrm{km} 120$ along the estuary due to convergence, which results in flood wave amplification (Fig. 3). Further upstream, the effects of friction will dominate more than the convergence and the high water levels start decreasing again, resulting in flood wave damping. This trend is the same for neap, spring and storm tides.

\subsection{Wetland elevation}

All scenarios are compared with the reference scenario (P.R.3 or P.S.3 for realistic or schematic scenarios respectively). 


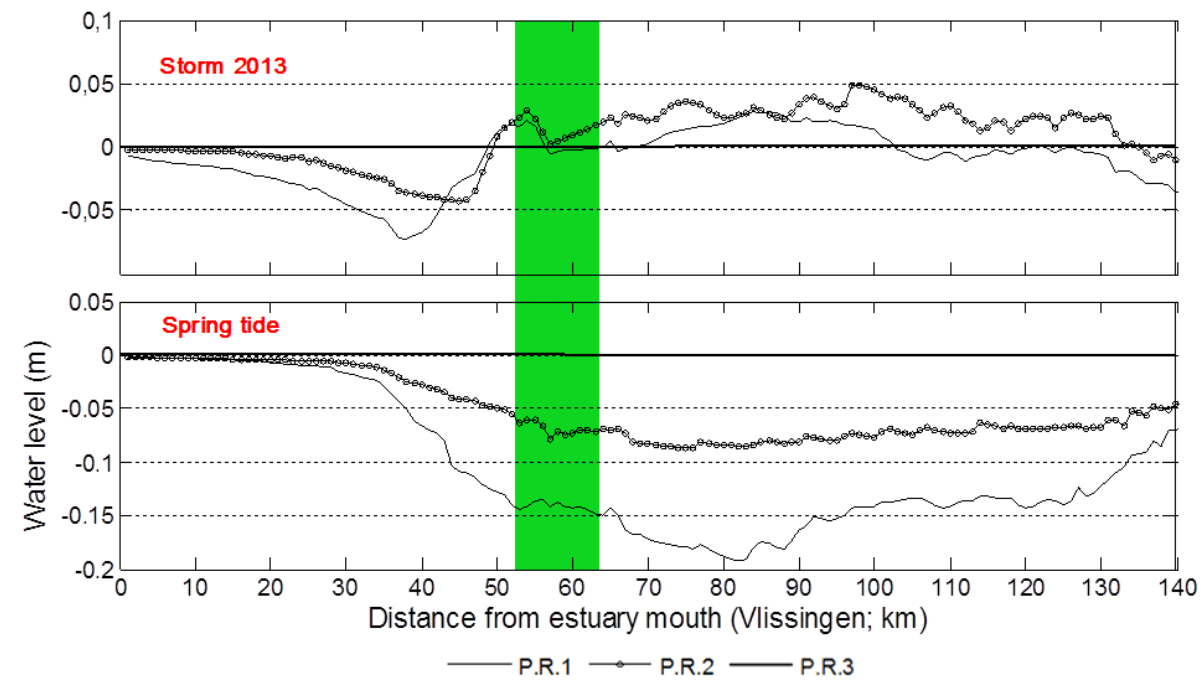

Figure 4. Scenarios with realistic wetland elevation relative to reference scenario P.R.3 (given by horizontal zero line). Scenarios given for spring and storm tide (2013). The green area shows the location of the Saeftinghe wetland along the estuary.

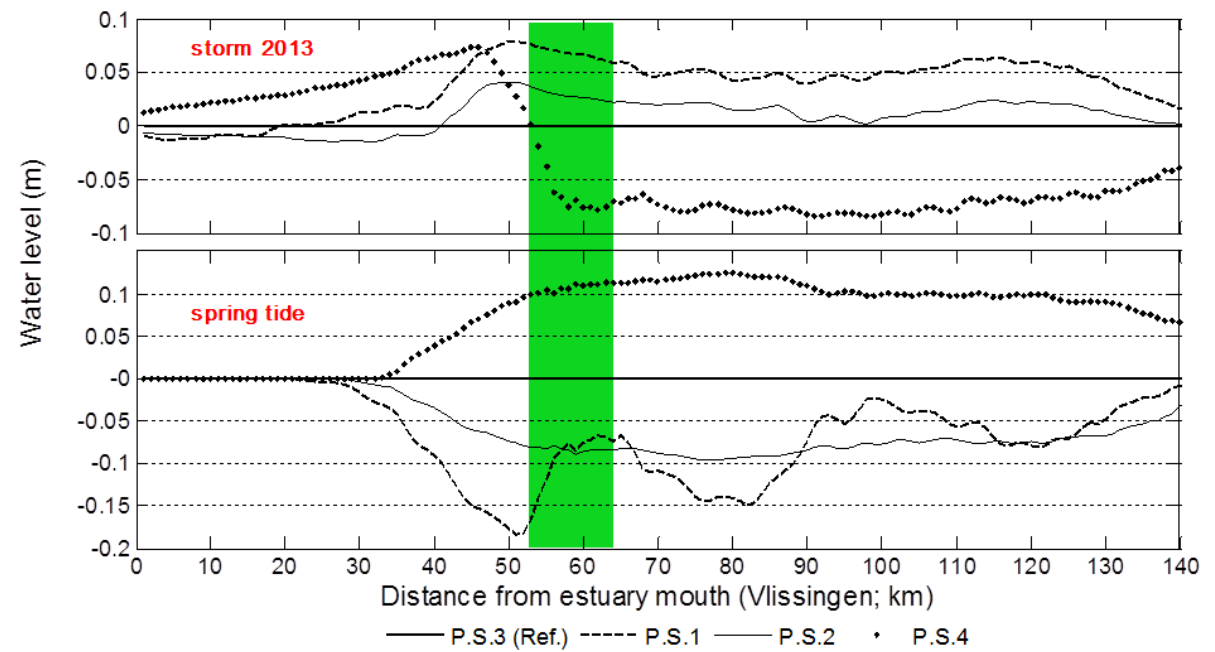

Figure 5. Scenarios with schematic wetland elevations relative to reference scenario P.S.3. Scenarios given for spring tide and storm tide (2013). The green area in the figure shows the location of the Saeftinghe wetland in the model.

This means that for each scenario the high water levels along the estuary are calculated relative to the high water levels of the reference scenario (Scenario - Reference). Negative values mean that a scenario results in lower high water levels compared to the reference scenario, and vice versa. The coloured area in the figures indicates the location of the wetland depending on its elevation.

\subsubsection{Scenarios with realistic wetland elevations}

For the scenarios with different realistic wetland elevations, Fig. 4 shows the differences in high water levels relative to the reference scenario for a spring tide and the 2013 storm. For a spring tide, the lower the wetland elevation, the more the water levels are attenuated along the estuary with a maxi- mum difference of almost $0.2 \mathrm{~m}$ upstream of the wetland area (Fig. 4). For the storm tide, the effects are more complex and differences between the different scenarios are much smaller than for the spring tide. Upstream differences are small $(<0.05 \mathrm{~m})$ while the largest differences (up to $0.07 \mathrm{~m}$ ) are located just downstream of the wetland. The lower the wetland elevation is, the lower the water levels are downstream, while upstream a slight increase in water levels is noticed (Fig. 4).

\subsubsection{Scenarios with schematic wetland elevations}

The same trend as with the realistic scenarios for a spring tide is seen in Fig. 5 for the schematic scenarios: the lower the wetland elevation, the lower the water levels become along 


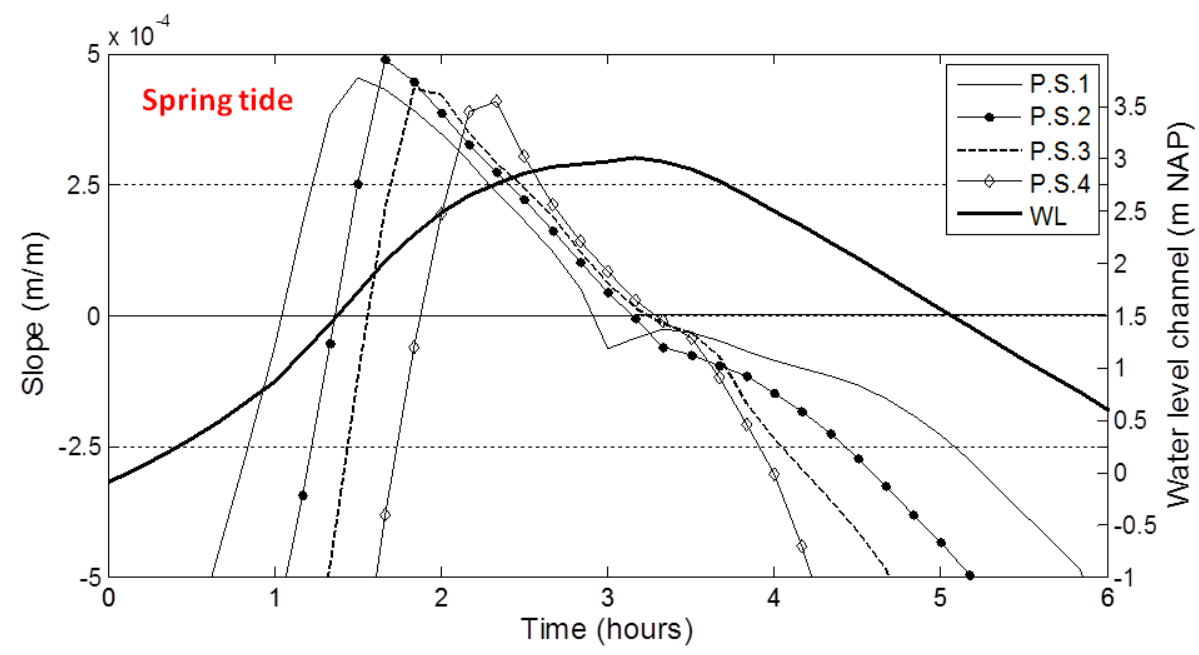

Figure 6. Water surface slopes for scenarios with different schematic wetland elevations (P.S.1, P.S.2, P.S.3 and P.S.4) for a spring tide between middle of the main estuarine channel and the wetland edge (distance was about $1000 \mathrm{~m}$ ). Positive slopes occur when the water floods from the main channel onto the wetland and negative slopes when the water drains again from the wetland towards the main channel. As a reference, the water level fluctuation in the main estuarine channel (thick black line) is given with values on the right $y$ axis.

the estuary. For the lowest elevation scenario (P.S.1) the maximum attenuation of high water levels occurs just downstream of the wetland and amounts to $0.18 \mathrm{~m}$ (as compared to the reference scenario P.S. 3 with wetland elevation $=1.85 \mathrm{~m}$ NAP). For the highest elevation scenario (P.S.4) water levels increase along the estuary to $0.13 \mathrm{~m}$ compared to the reference scenario.

For the storm tide the effects are again more complex and the difference between all scenarios is again much smaller compared to the spring tide. Scenarios P.S.1 and P.S.2 with lower wetland areas have higher water levels (up to $0.08 \mathrm{~m}$ ) especially just downstream of the wetland and upstream along most of the estuary. For the highest elevation (P.S.4) the high water levels first increase (up to $0.07 \mathrm{~m}$ ) downstream of the wetland. Near the wetland area the high water levels drop $0.14 \mathrm{~m}$ and stay low upstream of the wetland compared to the other scenarios. Overall, upstream of the wetland the storm tide is more attenuated when the marsh has a higher elevation, which is the opposite effect to the spring tide, which is more attenuated when the wetland has a lower elevation.

In order to further examine the differences in attenuation between the spring and storm tide, we analysed the time evolution of the water surface slope between the main estuarine channel and the adjacent edge of the wetland, which is the driving factor for water fluxes from the main estuarine channel onto the wetland (a higher positive slope indicates a faster water flux from the channel towards the wetland and vice versa). For the schematic scenarios the slopes for the spring and storm tide are plotted as a function of time in Figs. 6 and 7, respectively. For a spring tide, Fig. 5 shows that the lowest platform elevation (P.S.1) resulted in the strongest tidal attenuation along the estuary. Looking at the slopes in Fig. 6, the scenario with the lowest platform elevation (P.S.1) is the first for which water starts to flow onto the wetland (= when the slope becomes positive). The more the wetland elevation increases, the later and the less water flows onto the wetland. When the water level in the estuarine channel drops, the slopes become negative and the wetland is drained again towards the channel. In Fig. 6 the curves of the scenarios lie closer together at the start of wetland drainage then at the start of wetland flooding, which indicates that the wetland drainage is not so much influenced by wetland elevation than the wetland flooding.

For the storm tide of 2013 the highest platform elevation (P.S.4) results in the strongest attenuation of the storm tidal wave at the location of the wetland and upstream along the estuary (Fig. 5). In Fig. 7 the slopes for the different schematic platform elevations are plotted for the storm of 2013. The lowest platform (P.S.1) starts to store water first, but the slope reaches a lower maximum value and it decreases faster to zero than for the higher platform scenarios (P.S.2, P.S.3, P.S.4; see Fig. 7). The higher the platform the later it starts storing water, but the higher the maximum slope and the longer it can keep storing water (Fig. 7).

\subsection{Wetland surface area}

\subsubsection{Realistic scenarios with different wetland surface area}

The wetland surface area has a clear effect on tidal and storm surge attenuation along the estuary: the larger the wetland surface area, the larger the attenuation of the tidal wave along the estuary, both for the spring and storm tide (Fig. 8). The effect of the wetland surface area on attenuation is also bigger for the storm tide than for the spring tide. At spring tide 


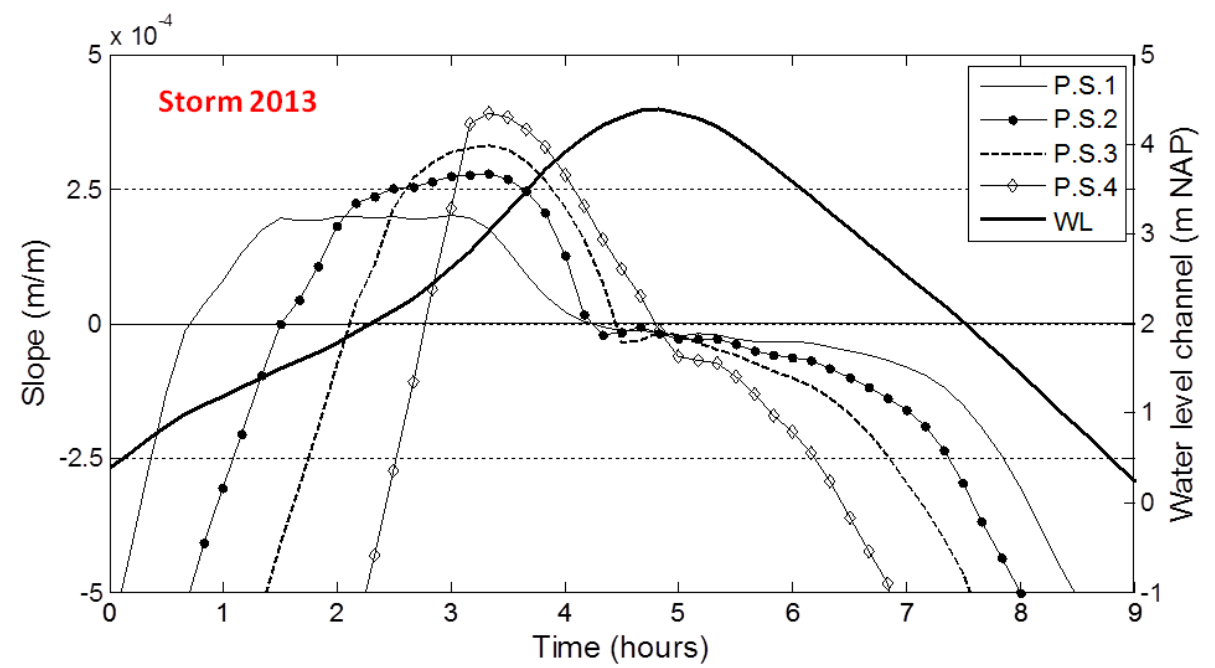

Figure 7. Water surface slopes for scenarios P.S.1, P.S.2, P.S.3 and P.S.4 for the storm tide of 1994 between middle of the main estuarine channel and the wetland edge (distance was about $1000 \mathrm{~m}$ ). Positive slopes occur when the water floods from the main channel onto the wetland and negative slopes when the water drains again from the wetland towards the main channel. As a reference, the water level fluctuation in the main estuarine channel (thick black line) is given with values on the right $y$ axis.

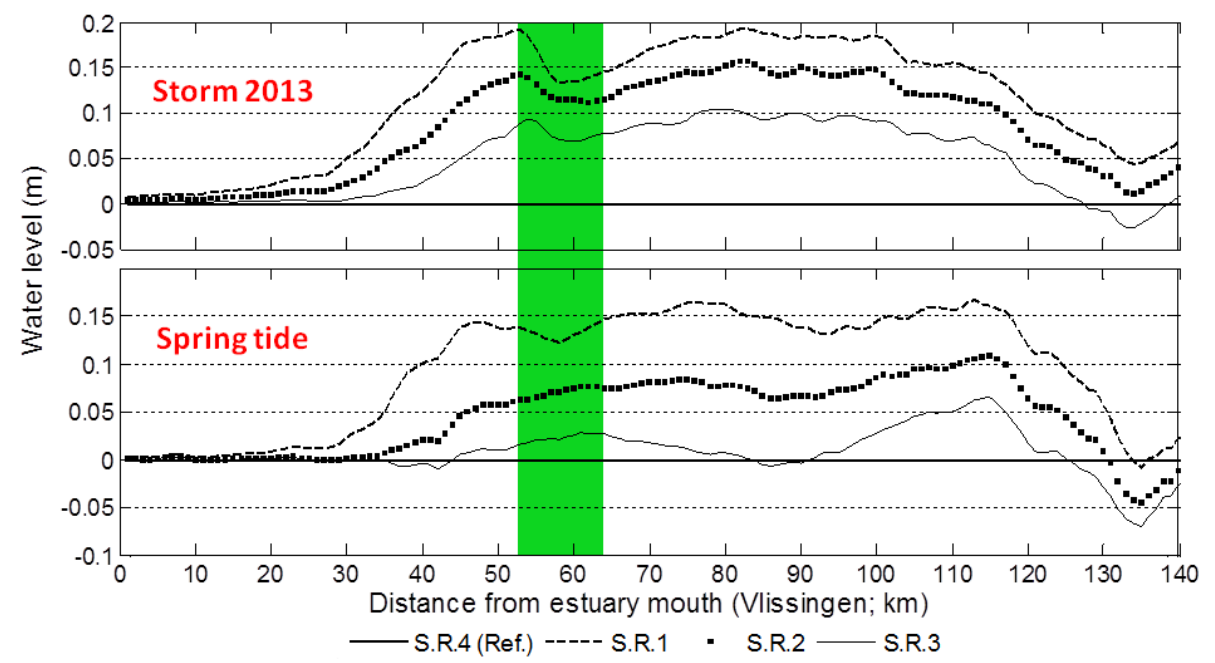

Figure 8. Scenarios for different realistic surface areas relative to reference scenario S.R.4. Scenarios given for a spring tide and storm tide (2013). The green area in the figure shows the location of the Saeftinghe wetland in the model.

the loss of 1000 ha (=S.R.3, see Fig. 2) in the back of the wetland area has little effect on the high water levels in the estuary $(<0.05 \mathrm{~m})$. But the effect of completely excluding the large wetland from the estuary (=S.R.1, see Fig. 2) is large: it increases the high water levels along most of the estuary and especially upstream of the wetland; the increase is largest at about $20 \mathrm{~km}$ upstream of the wetland and reaches a maximum of almost $0.17 \mathrm{~m}$ at spring tide and $0.19 \mathrm{~m}$ at storm tide.

\subsubsection{Schematic scenarios with different wetland surface area}

For a spring tide all scenarios gave similar results (Fig. 9). An increase in high water levels starts downstream of the large wetland area growing towards an increase of $0.17 \mathrm{~m}$ upstream and it starts decreasing again from $\mathrm{km} 85$ on. For the storm tide of 2013 the smallest surface area scenario (S.S.1) results in the highest increase in high water levels (up to $0.18 \mathrm{~m}$ ) compared to the reference scenario. The second scenario (S.S.2) also has higher water levels (but only up to $0.12 \mathrm{~m}$ ) compared to the reference. The scenario with surface area of 2000 ha (= S.S.3) results in high water levels 


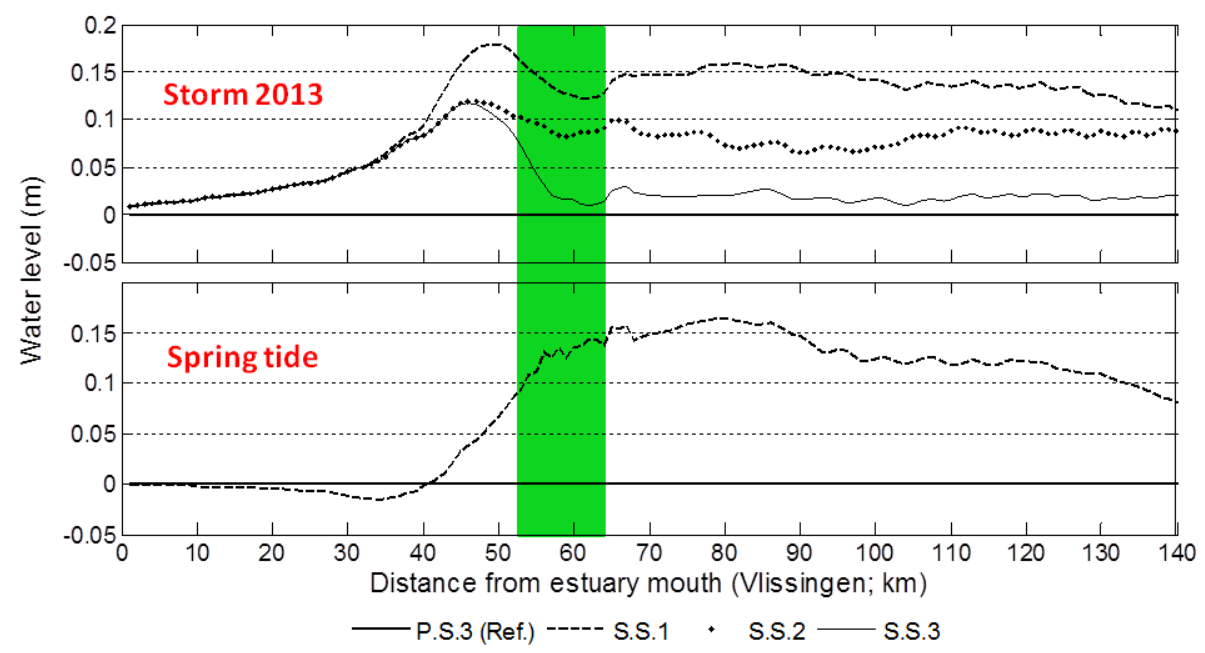

Figure 9. Scenarios for different schematic surface areas relative to reference scenario P.S.3. Scenarios given for a spring tide and the storm tide of 2013. For spring tide all scenarios gave nearly the same result. The green area in the figure shows the location of the Saeftinghe wetland in the model.

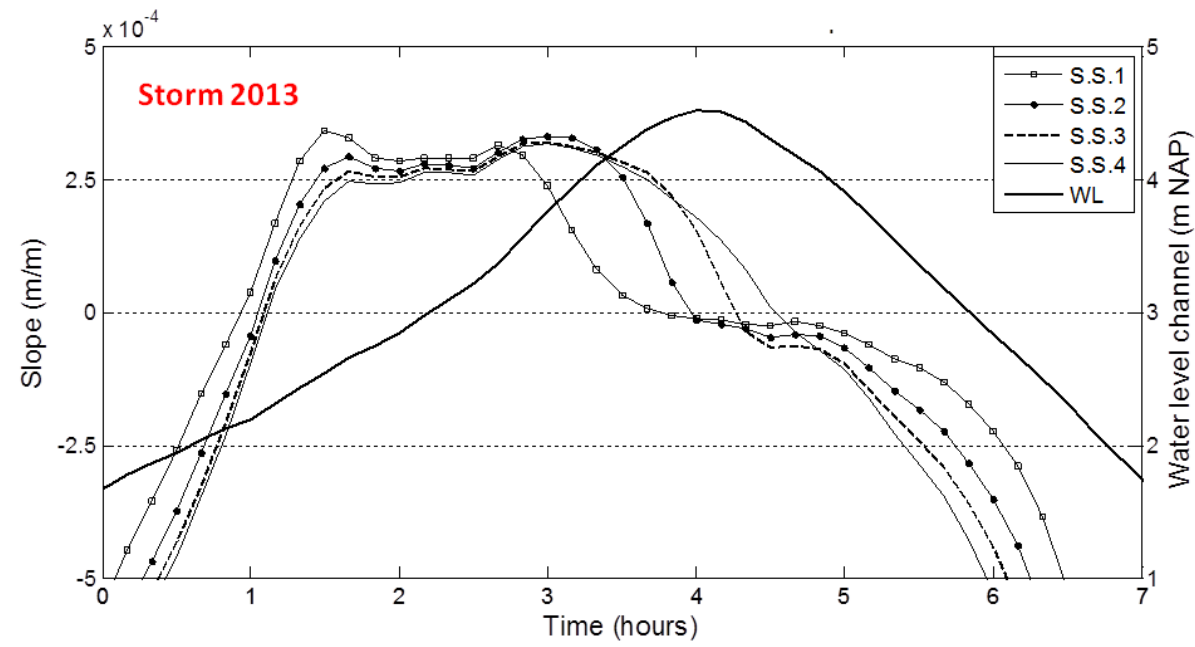

Figure 10. Water surface slope between main estuarine channel and wetland edge (distance between them was about $1000 \mathrm{~m}$ ) simulated for the storm tide of 2013 for different schematic scenarios with different wetland surface areas.

upstream of the wetland area that are comparable with the reference scenario. Downstream of the wetland the high water levels increase first (up to $0.12 \mathrm{~m}$ ) and drop when the wetland is reached. All scenarios with surface areas bigger than 2000 ha gave similar results as scenario S.S.3 for this storm tide, indicating that the extra intertidal storage area does not result in extra storm tide attenuation (to keep the figure readable these scenarios are not shown in Fig. 9).

Figure 10 presents the water surface slopes between the main estuarine channel and the wetland for the schematic surface area scenarios for the storm tide (2013). Because the wetland elevation is the same for all scenarios, the water starts flooding onto the wetland (= when the slope values become positive) at around the same time for all scenarios (with small variations in starting time between the scenarios due to small variations in remnant water from the previous spring tide) (Fig. 10). However, the end of wetland flooding (= when the slope values decrease again to zero) occurs at a different moment for the different scenarios. For the scenario with the smallest wetland area (S.S.1), the slope starts to decrease the earliest (Fig. 10). This is because when the wetland is smaller, the water storage capacity of the wetland is reached earlier and therefore water fluxes from the channel to the wetland stop earlier. Vice versa, the bigger the wetland area, the more water can enter the wetland and hence the longer the values of the slope stay high. We noticed that for scenarios S.S.5 and S.S.6, for which the wetland surface area is larger than scenario S.S.4, the end of wetland flooding (= when the slope values decrease to zero) occurs around the same time (not shown in Fig. 10 to keep this figure read- 


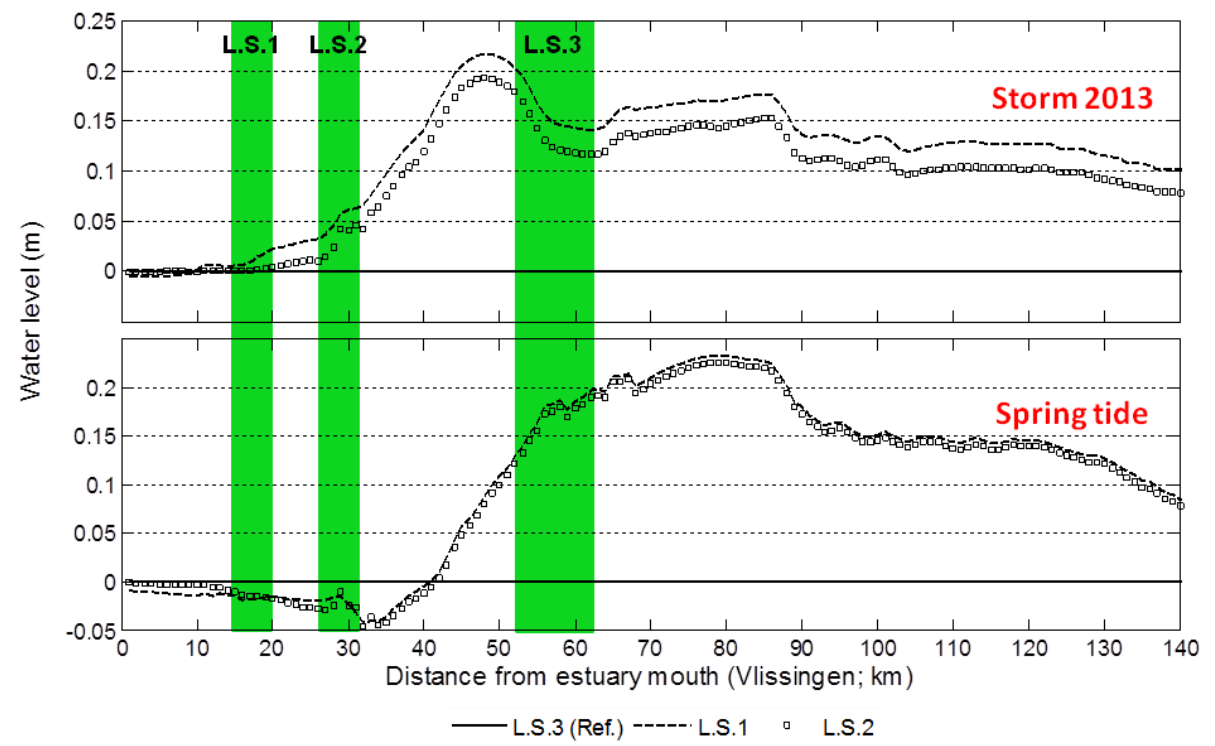

Figure 11. Scenarios with different wetland (with surface area $=3000$ ha) locations relative to reference scenario P.S.3 (= L.S.3). Scenarios given for spring and storm (2013) tide. The green areas in the figure show the locations of the different wetlands along the estuary in the model.

able). Figure 10 shows that when the slope for scenario S.S.4 becomes negative, the water level in the main estuarine channel is already decreasing, therefore limiting the time to store extra water on the wetland. Correspondingly, scenarios with wetland surface areas bigger than 2000 ha (S.S.4, S.S.5 and S.S.6 with 2500,3000 , and 3500 ha, respectively) resulted in similar attenuation of high water level during the storm tide. The same effect was observed for all scenarios for the spring tide. As the spring tide has a lower high water level, the time available for wetland flooding is shorter, and hence for all scenarios with different wetland size, the wetland flooding stops (i.e. water surface slopes decrease to zero) around the same time when the water level in the main estuarine channel has reached its maximum and start decreasing, hence resulting in similar water storage and similar attenuation of spring tides for all scenarios.

\subsection{Wetland location along the estuary}

\section{Schematic scenarios with different wetland location}

For the scenarios with a 3000 ha wetland area (scenarios L.S.1, L.S.2 and L.S.3) the attenuation of the tidal wave upstream of the wetland area is stronger if the wetland is located more upstream along the estuary, both for a spring and storm tide (Fig. 11). The difference in high water levels between L.S.1 (with wetland at $15-20 \mathrm{~km}$ from estuary mouth) and L.S.2 (at $26-32 \mathrm{~km})$ is small $(<0.03 \mathrm{~m})$. For scenario L.S.3 (with wetland at $53-64 \mathrm{~km}$ from estuary mouth), the attenuation of high water levels is much stronger and is highest just downstream the L.S.3 wetland location for the storm tide (up to $0.19 \mathrm{~m}$ lower than for L.S.2) and around $\mathrm{km} 80$ for spring tide (up to $0.23 \mathrm{~m}$ lower than L.S.2) (Fig. 11).

For the two scenarios with a 1500 ha wetland area, the scenario L.S.5 is compared with L.S.4, used as reference (= zero line in Fig. 12). The wetland, located most upstream (at 85$90 \mathrm{~km}$ ), results in the largest attenuation, i.e. $0.27 \mathrm{~m}$ at its location for the storm tide, and $0.17 \mathrm{~m}$ for spring tide. L.S.5 has however higher high water levels downstream around the location of the downstream wetland (at 53-64 km). For the spring and storm tide these higher water levels are 0.07 and $0.08 \mathrm{~m}$, respectively, higher than the reference (=L.S.4) (Fig. 12).

For locations more downstream in the estuary, the total flood volume that passes through a cross-section of the estuary is larger (illustrated for the storm tide in Table 2, fourth column). Consequently, wetlands of the same size and elevation, but located more downstream in the estuary, can store a smaller percentage of the total flood volume that passes through the estuary at that location (Table 2, sixth column). Additionally, the difference in water volume stored on the wetland (Table 2, fifth column) between the first three scenarios (with equal size and elevation but different locations along the estuary) is explained by the amplification of the high water levels in upstream direction along the estuary (Fig. 3). This results in longer periods of flooding and thus in larger volumes stored on the wetlands upstream of the estuary. Table 2 shows that the wetland of 1500 ha located most upstream (L.S.5) is most effective in storing the largest proportion of water that passes locally trough the estuarine channel. 


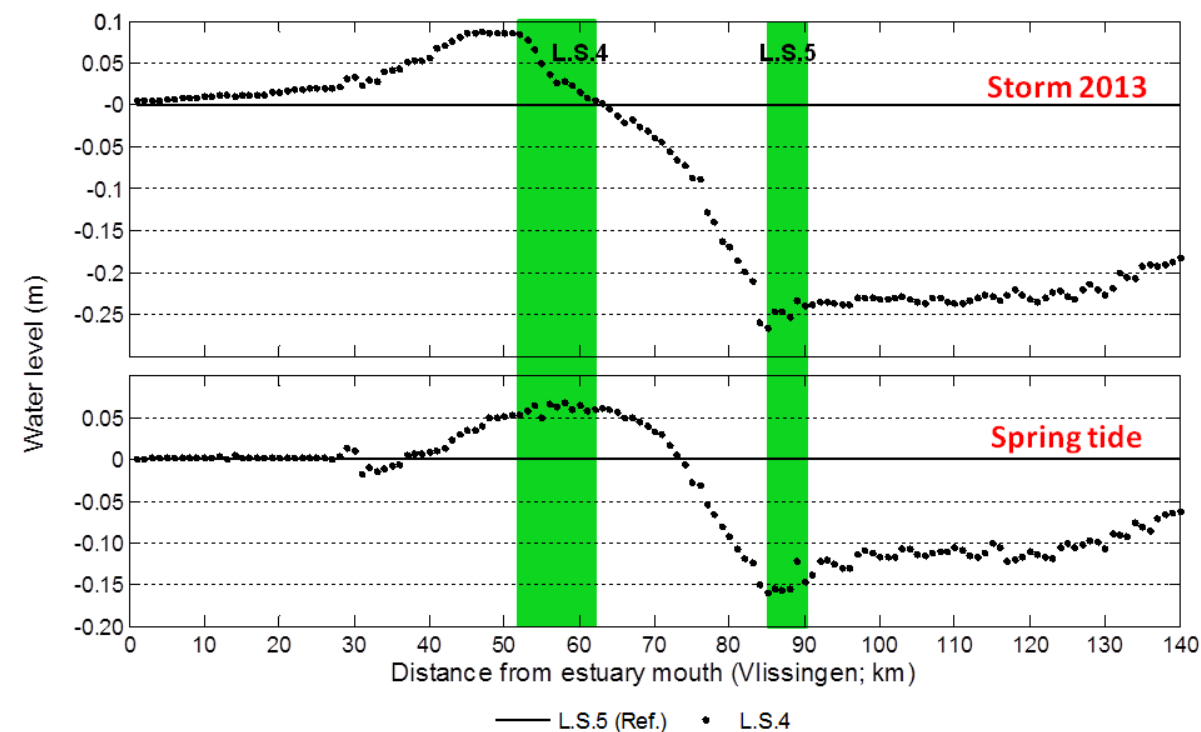

Figure 12. Scenarios with different wetland (with surface area $=1500 \mathrm{ha}$ ) locations relative to 1500 ha reference scenario (= L.S.4). Scenarios given for spring and storm (2013) tide. The green areas in the figure show the locations of the different wetlands along the estuary in the model.

Table 2. For the schematic scenarios with different wetland locations, the storm tidal flood volumes (storm 2013) that pass through the main estuarine channel next to the wetland and the volumes stored on top of the wetland are given. The last column shows the flood volumes stored onto the wetland as the percentage of the volume that passes through the main channel.

\begin{tabular}{lccrcr}
\hline Scenario & $\begin{array}{c}\text { Distance } \\
\text { from } \\
\text { estuary } \\
\text { mouth }\end{array}$ & $\begin{array}{c}\text { Wetland } \\
\text { surface } \\
\text { area } \\
(\mathrm{km})\end{array}$ & $\begin{array}{r}\text { Volume } \\
\text { passing } \\
\text { through } \\
\text { main } \\
\text { channel } \\
\left(\mathrm{m}^{3}\right)\end{array}$ & $\begin{array}{c}\text { Volume } \\
\text { stored } \\
\text { on the } \\
\text { wetland } \\
\left(\mathrm{m}^{3}\right)\end{array}$ & $\begin{array}{r}\text { Percentage } \\
\text { stored on } \\
\text { wetland } \\
(\%)\end{array}$ \\
& & $(\mathrm{ha})$ & & \\
\hline L.S.1 & 14 & 3000 & 1752915 & 45134 & 2.6 \\
L.S.2 & 26 & 3000 & 1441923 & 51530 & 3.6 \\
L.S.3 & 53 & 3000 & 592504 & 73473 & 12.4 \\
L.S.4 & 53 & 1500 & 584459 & 51353 & 8.8 \\
L.S.5 & 83 & 1500 & 228428 & 50841 & 22.3 \\
\hline
\end{tabular}

\section{Discussion}

The role of wetlands for attenuation of storm surges is over the last few years demonstrated by an increasing number of field-based studies (e.g. Costanza et al., 2008; Das and Vincent, 2009; Kraus et al., 2009; Gedan et al., 2011) and hydrodynamic modelling studies (e.g. Wamsley et al., 2010; Temmerman et al., 2012; Zhang et al., 2012; Sheng et al., 2012; Liu et al., 2013; Hu et al., 2015). All these studies focussed on the attenuation of storm surges that propagate through coastal wetlands, which we call here within-wetland attenuation, while to our knowledge few scientific studies exist on the effects of intertidal wetland properties on storm tide attenuation along estuaries, a mechanism we call here along-estuary attenuation (Fig. 1). Nevertheless, the principle of along-estuary flood attenuation by intertidal wetlands is known by estuarine management agencies, as conservation and restoration of intertidal wetlands is starting to be implemented on large scales as a crucial part of estuarine flood protection schemes in certain estuaries (Temmerman et al., 2013). After centuries of wetland reclamation, large areas of formerly reclaimed land are converted back into wetlands to cope with increasing flood risks due to climate change, for example in estuaries in the UK (so-called managed retreat: Pethick, 2002; French, 2006) and Belgium (Maris et al., 2007; Vandenbruwaene et al., 2011). Hydrodynamic modelling studies of estuarine wetland creation by managed retreat have been performed, focussing on effects on tidal asymmetry (Townend and Pethick, 2002) and tidal currents and discharges in the estuary (French, 2008). However, fundamental understanding of the effects of intertidal wetland properties on the degree and spatial extent of alongestuary flood attenuation is poorly developed.

In this paper we focus on the effect of different wetland characteristics, including wetland elevation, wetland surface area, and wetland location along the estuary, on the attenuation of spring and storm tides along the length of the estuary. In summary, for a spring tide lower wetland elevations result in more attenuation of high water levels along the estuary, while for a higher storm tide higher wetland elevations provide more attenuation compared to lower wetland elevations. For spring and storm tide a larger wetland surface area results in a better attenuation along the estuary. The schematic scenarios suggest that the increase in attenuation is non-linearly related to the increase in size and that for wetlands larger than 
a certain threshold there is no significant increase in attenuation anymore with increasing size. Finally a wetland of the same size and elevation, but located more upstream in the estuary, can store a larger proportion of the local flood volume and therefore has a larger attenuating effect on upstream high water levels.

\subsection{Wetland elevation}

For both the realistic and the schematic scenarios at spring tide large differences in high water levels along the estuary are shown in Figs. 4 and 5. For spring tide the lower the elevation and the lower the high water levels, the better the along-estuary attenuation becomes. Contrary, for storm tide a higher elevation provides a better along-estuary attenuation. For spring tide, lowering the wetland elevation, without changing anything about the rest of the bathymetry or topography of the estuary, implies that the tidal prism is locally increased. This will lower high water levels downstream and upstream from the wetland (Figs. 4 and 5). In natural systems such a change in the system will trigger a chain reaction and the system will change its bathymetry and try to reach a new equilibrium. A local increase in tidal prism will attract more flood water from downstream (Dyer, 1997; Townend and Pethick, 2002; Friess et al., 2014). A local decrease of tidal prism will remove accommodation space for flood water while downstream the system still delivers the same amount of flood water, resulting in higher high water levels (scenario P.S.4 in Fig. 5). The difference between spring tide and storm tide and the contrasting effect of the elevation on the along-estuary attenuation is explained by the timing and magnitude of water fluxes from the estuarine channel to the wetland. The time the water enters the wetland, the duration of flow onto the wetland and the rate at which water flows onto the wetland play an important role. We explain this by analysing the water surface slope between the estuarine channel and the wetland. The slopes in Fig. 6 show that for spring tide, the lower the elevation, the earlier the wetland is storing flood water. As long as water can keep flowing towards the wetland, the lower the elevation, the earlier the storing begins, the larger the effect on water levels along the estuary. Therefore the size of the area plays an important role (see discussion further below). For our model setup and wetland configuration in this estuary a spring tide is not able to fill in the wetland completely, even at lower elevations. Thus, the lower the elevation, the earlier the slope becomes positive (and the earlier the water enters the wetland), the longer it can keep filling with water, and the larger the effect on along-estuary attenuation as we can see in Figs. 4 and 5 for spring tide.

In contrast with a spring tide, a storm tide brings much more water to our wetland in our model setup. Now, depending on the elevation the wetland can be completely filled with water. A lower elevation causes an early start of the water storage (Fig. 7), but as the wetland gets completely filled with water the slope starts to decrease and falls back to zero. This happens much earlier than with higher elevated wetlands. For higher elevations, the wetland flooding starts later. The wetland's storage capacity is not filled completely and thus higher water surface slopes are reached during flooding of a higher elevated wetland. The available storage capacity keeps on filling to a time much closer to the high water level in the estuarine channel (Fig. 7). Hence there is an optimum wetland elevation for different tides depending on the maximum high water level. For the storm tide we modeled, if the wetland elevation is too low, the storage capacity is completely used, resulting in lower slopes between channel and wetland and slower filling rates. If the elevation is too high, filling the storage area starts too late and the full capacity is not used. In that case the slopes are high and the rate at which water flows onto the wetland is high, but the duration is too short, leading to a sub-optimal use of the storage capacity. Loder et al. (2009) stated that lower wetland elevation facilitated the landward propagation of coastal storm surges. Their focus is on within-wetland attenuation of a storm surge, and therefore does not incorporate the effects of wetland elevation on along-estuary attenuation. Wamsley et al. (2010) modeled the effect of coastal wetlands on storm surge attenuation. Their study focussed also on within-wetland attenuation, but they found that duration of the storm surge, similar to the duration of water flow onto the wetland in our study, is one of the key variables in storm surge attenuation. They also mention topography or wetland elevation as a key parameter, but like in Loder et al. (2009) the higher the elevation, the more difficult a storm surge can enter the wetland, whereas we describe elevation as a parameter to determine storage capacity, duration of flow onto the wetland and time at which the flow starts to move onto the wetland. Temmerman et al. (2012) also investigate the within-wetland attenuation of storm floods and mention elevation to be of minor importance for flood propagation. But they tested only small changes in elevation caused by erosion due to marsh vegetation die-off.

\subsection{Wetland surface area}

The realistic scenarios (S.R.1, S.R.2, S.R.3 and S.R.4) showed that for increasing wetland surface areas the alongestuary attenuation will increase. These results lie within the expectations that when the storage capacity increases, attenuation increases. The schematic scenarios (S.S.1 to S.S.6) show however that there is an upper limit to this increasing surface area for a specific elevation (i.e. $2 \mathrm{~m}$ NAP in our case; effect of elevation discussed in previous section). For a certain elevation a further increase in surface area will no longer result in increased attenuation. Although storage capacity is increased, it will not be used anymore, because the duration of flow onto the wetland is limited, depending on the form of the tidal wave that passes the area. At a certain moment water levels will start to decrease in the estuarine channel, resulting 
in negative slopes from the wetland to the estuary and water starts to drain from the wetland (Fig. 10). In other words a further increase in wetland surface area will not result in an increase in water storage on the wetland due to the lack of time to fill this storage area. If larger storms would enter the estuary, this would result in higher water levels relative to the wetland elevation and so the slope will stay positive for a longer time, filling a larger storage space, if available. The results suggest that there is a local optimal surface area for a wetland with a specific elevation and a specific location within the estuary. Further work is planned to investigate the possible presence of this optimum in surface area in function of the magnitude of the storm surge, the wetland elevation and the location within the estuary.

The realistic scenarios (S.R.2, S.R.3 and S.R.4) have large drainage channels, which are wider and deeper near their connection with the main estuarine channel. This means that cutting of a large part at the landward side of the wetland also results in a decrease of the average elevation of the wetland site. So for these scenarios a change in surface area also results in a change in average elevation (effects discussed in previous section). The schematic scenarios (S.S.1 to S.S.6) with a flat wetland topography show only the effect of the surface area. It is clear that for a certain storm tide with specific maximum high water level there is a limitation on the time that water can flow onto the tidal wetland, and that this time of flooding continues longer as the wetland surface area is larger. Figure 10 shows that for smaller wetland areas (like S.S.1) the water surface slope decreases to zero far before the high water level in the main estuarine channel is reached. This is because small wetland areas are more rapidly filled with flood water, hence decreasing the slope and discharge towards the wetland before the peak water level in the main estuarine channels is reached. Accordingly, smaller wetland areas (like S.S.1) are less effective in attenuating peak water levels along the estuary during a storm tide (Fig. 9). If the wetland area is large enough (like S.S.2, S.S.3 and S.S.4) the water surface slope and hence the discharge towards the wetland remain high, until the water level in the main estuarine channel will fall again, decreasing the slope and thus the discharge. Our results imply that the higher the incoming storm tide, the longer the water surface slope towards the wetland can stay positive and the larger the wetland surface area needs to be to maintain this slope and to attenuate the storm tide most effectively. In this respect if we keep the width (i.e. the length of connection between wetland and estuarine channel) of the wetland fixed, like in our scenarios, increasing the surface area means increasing the depth (i.e. the length, perpendicular to the estuarine channel and towards the back of the wetland). Increasing the depth means that water needs a longer time to reach the back of the wetland and so to use all the available storage capacity. If we keep the depth fixed and increase the surface area, it means that the wetland area is widened and this will give different results for the along-estuary attenuation. However this was not tested in this study.

An increase in intertidal surface area can have large effects on hydrodynamics up- and downstream of the affected intertidal area by increasing the tidal prism. Townend and Pethick (2002) showed this with a conceptual and idealized model. They increased the tidal prism by managed retreat of dikes and levees and show that this will increase the size of the estuarine channels to accommodate for the increased water demand by the added intertidal area (see also Fries et al., 2014), possibly changing the characteristics of the system (from flood to ebb dominancy). Townend and Pethick conclude that increasing the intertidal surface area will decrease tidal water levels and decrease flood risk. We come to the same conclusion in this paper and share their concern that interfering in the tidal prism will possibly change the morphodynamics of the estuary. By choosing elevations of $2 \mathrm{~m}$ NAP for our schematic scenarios interference with a normal spring-neap tidal cycle will be minimized, i.e. it will not affect the tidal prism for most tides (like the spring tide scenarios in Fig. 9). Therefore the effects on the morphodynamics of the estuary (which is governed by regular neap to spring tides instead of exceptional storm tides) will be minimal.

Surface area was also found to be an important parameter in previous studies on storm surge attenuation within foreshore wetlands. The larger these areas, the more high water levels reduce during storm surges within and behind coastal wetlands (e.g. Loder et al., 2009; Wamsley et al., 2010). In these studies the surface area is more a measure for the length that friction can act on the flood wave, whereas in our study the surface area is a parameter determining the total storage capacity of a wetland.

\subsection{Wetland location along the estuary}

Table 2 shows a decrease in total storm flood volumes in the main estuarine channel in upstream direction. As a consequence, the more upstream the less flood water needs to be stored to have a similar effect on the tidal wave attenuation along the estuary. Furthermore, the high water levels are amplified in upstream direction by the funnel shape of the estuary (until the location where the effect of friction becomes dominant over convergence; Fig. 3) so that more upstream located wetlands with the same elevation will be flooded by higher water levels and thus during a longer time. As a result, the degree of attenuation of a spring tide is different for the wetlands with different locations (Figs. 11 and 12). Table 2 also shows that more upstream smaller surface areas can store higher percentages of the total storm flood flow at the specific locations. So the higher the percentage of flood water stored onto the wetland the larger the attenuation. The results show further a spatial extent of high water level reduction along the estuary. Figure 12 shows clearly for the most upstream wetland at storm tide that the effect of attenuation is situated mainly upstream. This means that when we want 
to have a specific flood wave attenuation at a specific reach along the estuary, the location where we want to add extra wetland surface area is very important. If the wetland is located too far downstream from this location it will need to have a larger surface area to create the same amount of attenuation than a wetland that is located near our area of interest.

In real estuaries all these parameters interfere with each other in a complex way and when discussing the impact of one of them, we cannot ignore the others. For example if the wetland elevation is increased the water will enter the wetland at a later time and so the duration of flow onto the wetland will be shorter and thus less surface area (storage capacity) is needed. Further, more characteristics are important, like the connection between wetland and the estuarine channel. The longer this connection length, the more water can access the wetland. This was not taken into account in this paper, but will be a topic for further research.

\section{Conclusions}

This paper presented the results of a hydrodynamic model study on the along-estuary propagation of a spring and storm tide and the attenuation effect of different geometric characteristics of a tidal wetland, i.e. the wetland elevation, surface area, and location along the estuary. Based on our model results the following conclusions can be drawn:

1. For a spring tide lower wetland elevations result in more attenuation of high water levels along the estuary, while for a higher storm tide higher elevations provide more attenuation compared to lower wetland elevations. The wetland elevation relative to the height of the tidal wave determines the start and duration of flow from the estuarine channel to the wetland. We found that there is an optimal wetland elevation relative to the height of the tidal wave, for which the water fluxes from the estuarine channel reach a maximal rate and duration so that the storage capacity of the wetland is most optimally used.

2. Larger wetland surface areas result in more flood wave attenuation along the estuary. For a specific wetland elevation and location along the estuary, the amount of flood wave attenuation does not further increase with increasing wetland area above a certain wetland depth, i.e. the distance from the estuarine channel, because time is lacking to fill and use the storage capacity of that additional space.

3. The more downstream in an estuary, the larger the flood volumes in the main estuarine channel will be and the larger the wetland surface area will have to be to have a significant effect on upstream tidal and storm tide attenuation along the estuary. A wetland of the same size will store a smaller percentage of the total flood volume at a more downstream location, than at a more upstream location, and therefore will have a smaller effect on attenuation of high water levels upstream along the estuary.

In conclusion, this paper provides a first insight in the separate effects of geometric properties of estuarine tidal wetland on tidal and storm tide attenuation along an estuary. Further research is necessary for example to account for the combined effects of wetland geometric properties, the effects of multiple wetlands located at different positions along an estuary, and effects of storm properties, such as duration and intensity, on flood attenuation along an estuary, in order to support a better understanding and wider implementation of nature-based adaptation to increasing flood risks associated with storms (Temmerman et al., 2013).

Acknowledgements. The authors like to thank the Antwerp Port Authority and the Dehousse scholarship of the Antwerp University for the financial support. We like to acknowledge the technical support of the Flanders Hydraulics Research institute. We like to thank Rijkswaterstaat for all measurements and data sharing. Finally we would like to thank the developers of the Telemac system and Blue Kenue software.

Edited by: J. Brown

Reviewed by: C. Ibanez and another anonymous referee

\section{References}

Alongi, D. M.: Present state and future of the world's mangrove forests, Environ. Conserv., 29, 331-349, 2002.

Baeyens, W., van Eck, B., Lambert, C., Wollast, R., and Goeyens, L.: General description of the Scheldt estuary, Hydrobiologia, 34, 83-107, 1998.

Barbier, E. B., Hacker, S. D., Kennedy, C., Koch, E. W., Stier, A. C., and Silliman, B. R.: The value of estuarine and coastal ecosystem services, Ecol. Monogr., 81, 169-193, 2011.

Barbier, E. B., Georgiou, I. Y., Enchelmeyer, B., and Reed, D. J.: The Value of Wetlands in Protecting Southeast Louisiana from Hurricane Storm Surges, Plos One, 8, e58715, doi:10.1371/journal.pone.0058715, 2013.

Bullock, A. and Acreman, M.: The role of wetlands in the hydrological cycle, Hydrol. Earth Syst. Sci., 7, 358-389, doi:10.5194/hess-7-358-2003, 2003.

Chow, V. T.: Open-channel hydraulics, McGraw-Hill Book Co., New York, 680 pp., 1959.

Church, J. A., Clark, U. P., Cazenave, A., Gregory, J. M., Jevrejeva, S., Levermann, A., Merrifield, M. A., Milne, G. A., Nerem, R. S., Nunn, P. D., Payne, A. J., Pfeffer, W. T., Stammer, D., and Unnikrishnan, A. S.: Sea Level Change, in: Climate Change 2013: The Physical Science Basis. Contribution of Working Group I to the Fifth Assessment Report of the Intergovernmental Panel on Climate Change, edited by: Stocker, T. F., Qin, D., Plattner, G.K., Tignor, M., Allen, S. K., Boschung, J., Nauels, A., Xia, Y., Bex, V., and Midgley, P. M., Cambridge University Press, Cambridge, UK and New York, NY, USA, 2013. 
Costanza, R., Perez-Maqueo, O., Martinez, M. L., Sutton, P., Anderson, S. J., and Mulder, K.: The value of coastal wetlands for hurricane protection, Ambio, 37, 241-248, 2008.

Cox, T. J. S., Maris, T., De Vleeschauwer, P., De Mulder, T., Soetaert, K., and Meire, P.: Flood control areas as an opportunity to restore estuarine habitat, Ecol. Eng., 28, 55-63, 2006.

Das, J. W. and Vincent, J. R.: Mangroves protected villages and reduced death toll during Indian super cyclone, P. Natl. Acad. Sci. USA, 106, 7357-7360, 2009.

Dyer, K. R.: Estuaries: A Physical Introduction, John Wiley \& Sons Ltd, New York, 1997.

Emanuel, K.: Increasing destructiveness of tropical cyclones over the past 30 years, Nature, 436, 686-688, 2005.

French, J. R.: Hydrodynamic modelling of estuarine flood defence realignment as an adaptive management response to sea-level rise, J. Coast. Res., 24, 1-12, 2008.

French, P. W.: Coastal and Estuarine Management, in: Routledge Environmental Management Series, Routledge, London, 1997.

French, P. W.: Managed realignment - The developing story of a comparatively new approach to soft engineering, Estuar. Coast Shelf. S., 67, 409-423, 2006.

Friess, D. A., Möller, I., Spencer, T., Smith, G. M., Thomson, A. G., and Hill, R. A.: Coastal saltmarsh managed realignment drives rapid breach inlet and external creek evolution, Freiston Shore (UK), Geomorphology, 208, 22-33, 2014.

Gaslikova, L., Grabemann, I., and Groll, N.: Changes in North Sea storm surge conditions for four transient future climate realizations, Nat. Hazards, 66, 1501-1518, 2013.

Gedan, K. B., Kirwan, M. L., Wolanski, E., Barbier, E. B., and Silliman, B. R.: The present and future role of coastal wetland vegetation in protecting shorelines: answering recent challenges to the paradigm, Climatic Change, 106, 7-29, 2011.

Grinsted, A., Moore, J. C., and Jevrejeva, S.: Projected Atlantic hurricane surge threat from rising temperatures, P. Natl. Acad. Sci. US, 110, 5369-5373, 2013.

Hallegatte, S., Green, C., Nicholls, R. J., and Corfee-Morlot, J.: Future flood losses in major coastal cities, Nat. Clim. Change, 3, 802-806, 2013.

Hanson, S., Nicholls, R., Ranger, N., Hallegatte, S., Corfee-Morlot, J., Herweijer, C., and Chateau, J.: A global ranking of port cities with high exposure to climate extremes, Climatic Change, 104, 89-111, 2011.

Hu, K. L., Chen, Q., and Wang, H. Q.: A numerical study of vegetation impact on reducing storm surge by wetlands in a semienclosed estuary, Coast. Eng., 95, 66-76, 2015.

Kirwan, M. L. and Temmerman, S.: Coastal marsh response to historical and future sea-level acceleration, Quaternary Sci. Rev., 28, 1801-1808, 2009.

Kirwan, M. L., Guntenspergen, G. R., D’Alpaos, A., Morris, J. T., Mudd, S. M., and Temmerman, S.: Limits on the adaptability of coastal marshes to rising sea level, Geophys. Res. Lett., 37, L23401, doi:10.1029/2010GL045489, 2010.

Knutson, T. R., McBride, J. L., Chan, J., Emanuel, K., Holland, G., Landsea, C., Held, I., Kossin, J. P., Srivastava, A. K., and Sugi, M.: Tropical cyclones and climate change, Nat. Geosci., 3, 157$163,2010$.

Krauss, K. W., Doyle, T. W., Doyle, T. J., Swarzenski, C. M., From, A. S., Day, R. H., and Conner, W. H.: Water level observations in mangrove swamps during two hurricanes in Florida, Wetlands, 29, 142-149, 2009.

Lin, N., Emanuel, K., Oppenheimer, M., and Vanmarcke, E.: Physically based assessment of hurricane surge threat under climate change, Nat. Clim. Change, 2, 462-467, 2012.

Liu, H. Q., Zhang, K. Q., Li, Y. P., and Xie, L.: Numerical study of the sensitivity of mangroves in reducing storm surge and flooding to hurricane characteristics in southern Florida, Cont. Shelf Res., 64, 51-65, 2013.

Loder, N. M., Irish, J. L., Cialone, M. A., and Wamsley, T. V.: Sensitivity of hurricane surge to morphological parameters of coastal wetlands, Estuar. Coast. Shelf S., 84, 625-636, 2009.

Lovelace, J. K.: Storm-tide elevations produced by Hurricane Andrew along the Louisiana coast, August 25-27, 1992, Open File Report 94-371, 1994.

Maris, T., Cox, T., Temmerman, S., De Vleeschauwer, P., Van Damme, S., De Mulder, T., Van den Bergh, E., and Meire, P.: Tuning the tide: creating ecological conditions for tidal marsh development in a flood control area, Hydrobiologia, 588, 31-43, 2007.

McGee, B. B. D., Goree, B. B., Tollett, R. W., Woodward, B. K., and Kress, W. H.: Hurricane Rita Surge Data, Southwestern Louisiana and Southeastern Texas, September to November 2005, US Geological Survey Data Series 220, US Geological Survey, 2006.

Meire, P., Ysebaert, T., Van Damme, S., Van den Bergh, E., Maris, T., and Struyf, E.: The Scheldt estuary: a description of a changing ecosystem, Hydrobiologia, 540, 1-11, 2005.

Meire, P., Dauwe, W., Maris, T., Peeters, P., Coen, L., Deschamps, M., Rutten, J., and Temmerman, S.: The recent "Saint Nicholas" storm surge in the Scheldt estuary: the Sigma plan proves its efficiency!, ECSA Bulletin, 62, 19-23, 2014.

Millennium Ecosystem Assessment: Ecosystems and human wellbeing: current state and trends, Island Press, Washington, 2005.

Möller, I., Kudella, M., Rupprecht, F., Spencer, T., Paul, M., van Wesenbeeck, B. K., Wolters, G., Jensen, K., Bouma, T. J., Miranda-Lange, M., and Schimmels, S.: Wave attenuation over coastal salt marshes under storm surge conditions, Nat. Geosci., 7, 727-731, 2014.

Pethick, J.: Estuarine and tidal wetland restoration in the United Kingdom: Policy versus practice, Restor. Ecol., 10, 431-437, 2002.

Phillips, J. V. and Tadayon, S.: Selection of Manning's roughness coefficient for natural and constructed vegetated and nonvegetated channels, and vegetation maintenance plan guidelines for vegetated channels in central Arizona, US Geological Survey Scientific Investigations Report 2006-5108, US Geological Survery, Reston, Virginia, p. 41, 2006.

Resio, D. T. and Westerink, J. J.: Modelling the physics of storm surges, Physics Today, 61, 33-38, 2008.

Sheng, Y. P., Lapetina, A., and Ma, G. F.: The reduction of storm surge by vegetation canopies: Three-dimensional simulations, Geophys. Res. Lett., 39, L20601, doi:10.1029/2012GL053577, 2012.

Temmerman, S., De Vries, M. B., and Bouma, T. J.: Coastal marsh die-off and reduced attenuation of coastal floods: a model analysis, Global Planet. Change, 92-93, 267-274, 2012.

Temmerman, S., Meire, P., Bouma, T. J., Herman, P. M. J., Ysebaert, T., and De Vriend, H. J.: Ecosystem-based coastal 
defense in the face of global change, Nature, 504, 79-83, doi:10.1038/nature12859, 2013.

Townend, I. and Pethick, J.: Estuarine flooding and managed retreat. Philos. T. Roy. Soc. A, 1796, 1477-1495, doi:10.1098/rsta.2002.1011, 2002.

Van Damme, S., Struyf, E., Maris, T., Ysebaert, T., Dehairs, F., Tackx, M., Heip, C., and Meire, P.: Spatial and temporal patterns of water quality along the estuarine salinity gradient of the Scheldt estuary (Belgium and The Netherlands): results of an integrated monitoring approach, Hydrobiologia, 540, 29-45, 2005.

Vandenbruwaene, W., Maris, T., Cox, T. J. S., Cahoon, D. R., Meire, P., and Temmerman, S.: Sedimentation and response to sea-level rise of a restored marsh with reduced tidal exchange: Comparison with a natural tidal marsh, Geomorphology, 130, 115-126, 2011.

Vandenbruwaene, W., Plancke, Y., Verwaest, T., and Mostaert, F.: Interestuarine comparison: Hydro-geomorphology: Hydro- and geomorphodynamics of the TIDE estuaries Scheldt, Elbe, Weser and Humber, WL Report 770_62b, 2013, Flanders Hydraulics Research, Antwerp, Belgium, 2013.
Wamsley, T. V., Cialone, M. A., Smith, J. M., Ebersole, B. A., and Grzegorzewski, A. S.: Influence of landscape restoration and degradation on storm surge and waves in southern Louisiana, Nat. Hazards, 51, 207-224, 2009.

Wamsley, T. V., Cialone, M. A., Smith, J. M., Atkinson, J. H., and Rosati, J. D.: The potential of wetlands in reducing storm surge, Ocean Eng., 37, 59-68, 2010.

Wang, C. and Temmerman, S.: Does bio-geomorphic feedback lead to abrupt shifts between alternative landscape states? An empirical study on intertidal flats and marshes, J. Geophys. Res.-Earth, 118, 229-240, 2013.

Webster, P. J., Holland, G. J., Curry, J. A., and Chang, H. R.: Changes in tropical cyclone number, duration, and intensity in a warming environment, Science, 309, 1844-1846, 2005.

Willems, P., Guillou, A., and Beirlant, J.: Bias correction in hydrologic GPD based extreme value analysis by means of a slowly varying function, J. Hydrol., 338, 221-236, 2007.

Zhang, K. Q., Liu, H., Li, Y., Xu, H., Shen, J., Rhome, J., and Smith, T. J.: The role of mangroves in attenuating storm surges, Estuar. Coast. Shelf Sci., 102-103, 11-23, 2012. 